\title{
STUDI PERBANDINGAN JUS APEL DAN JUS ALPUKAT TERHADAP PENURUNAN KADAR KOLESTEROL PADA ORANG YANG MENGALAM HIPERKOLESTEROLEMIA DI WILAYAH KERJA PUSKESMAS BANGKINANG KOTA
}

\author{
Muhammad Nurman ${ }^{1}$, Ainul Afifah ${ }^{2}$ \\ Program Studi Sarjana Keperawatan \\ Universitas Pahlawan Tuanku Tambusai \\ m.nurman311277@gmail.com
}

\begin{abstract}
Abstrak
Hiperkolesterol merupakan salahsatu penyakit umum yang diderita oleh masyarakat Indonesia bahkan di dunia. Penyakit ini sangat berdampak besar jika tidak ditangani secara intensif dan bisa berujung kematian. Penyakit hiperkolesterol dapat dikendalikan dengan pengobatan farmakologi dalam mengatasi penurunan kadar kolesterol adalah dengan mengkonsumsi jus apel dan jus alpukat. Tujuan penelitian adalah untuk mengetahui perbandingan efektifitas pemberian jus apel dan jus alpukat terhadap kadar kolesterol pada orang yang mengalami hiperkolesterolemia di Wilayah Kerja Puskesmas Bangkinang Kota Tahun 2019. Penelitian ini menggunakan metode quasi experiment dengan rancangan two group pre-test-posttest. Populasi dalam penelitian adalah seluruh orang yang mengalami Hiperkolesterolemia yang ada di Wilayah Kerja Puskesmas Bangkinang Kota pada katagori umur 45-54 tahun yang berjumlah 106 orang, sedangkan sampel yang digunakan yaitu 30 oarang. 15 orang yang mengkonsumsi jus apel dan 15 orang yang mengkonsumsi jus alpukat yang diambil secara purposive sampling. Hasil penelitiannya berdasarkan analisa bivariat dengan uji paired t tes di dapatkan ada pengaruh antara kadar kolesterol sebelum dan sesudah pemberian jus apel dengan $\mathrm{p}=0,000$ mean $78,4 \mathrm{mg} / \mathrm{dl}$ dan jus alpukat dengan $\mathrm{p}=0,000$ mean $58,3 \mathrm{mg} / \mathrm{dl}$ pada orang yang mengalami hiperkolesterolemia, sehingga dapat disimpulkan bahwa jus apel lebih efektif dari pada jus alpukat dalam menurunkan kadar kolesterolemia. Diharapkan kepada petugas puskesmas dapat untuk mensosialisasikan pentingnya mengkomsumsi jus apel dalam rangka menurunkan angka penyakit hiperkolesterolemia.
\end{abstract}

\section{Kata Kunci: Perbandingan, Jus Apel. Jus Alpukat, Hiperkolesterolemia}

$\triangle$ Corresponding author :

Address : Jl. Tuanku Tambusai No. 23 Bangkinang

Email : m.nurman311277@gmail.com

Phone : 081378481097 


\section{PENDAHULUAN}

Kolesterol adalah senyawa lemak kompleks dalam aliran darah atau sel tubuh yang dibutuhkan untuk pembentukan dinding sel dan sebagai bahan baku beberapa hormone. Kolesterol dalam tubuh manusia dapat dihasilkan sendiri oleh organ hati, korteks, adrenal, kulit, usus, lambung dan otak. Kolesterol juga dapat diperoleh dari luar tubuh yaitu melalui makanan hewani seperti daging, unggas, ikan, margarin, dan susu (Maulidi 2016 dalam Hasanah, 2017)

Tubuh membutuhkan beberapa kolesterol untuk berfungsi dengan baik. Dinding sel atau membran membutuhkan kolesterol untuk memproduksi hormone, vitamin $\mathrm{D}$, dan asam empedu yang membantu mencerna lemak. Tapi yang dibutuhkan tubuh hanya dalam jumlah kolesterol terbatas untuk memenuhi kebutuhannya. Bila terlalu banyak maka masalah kesehatan akan timbul pada tubuh seseorang (Jevuska 2013)

Penyakit kolesterol merupakan salah satu penyakit yang masih banyak terjadi pada zaman modern ini. Tingginya kadar kolesterol dalam tubuh akan menjadi pemicu timbulnya berbagai macam penyakit yang lain. Kolesterol yang tinggi tidak hanya dialami oleh orang yang brtubuh gemuk tetapi orang yang bertubuh kurus pun tidak berarti terbebas dari penyakit kolesterol. Penyakit kolesterol juga dapat menimpa orang-orang yang masih muda atau berbagai kalangan umur. Kolesterol terdapat di setiap tubuh manusia. Dalam kondisi normal, senyawa ini tidak berbahaya. Kolesterol akan menjadi merugikan dan dianggap sebagai penyebab berbagai penyakit mematikan, seperti jantung coroner, stroke dan diabetes jika jumlahnya melebihi batas normal (Amir, 2012 dalam Uswatun hasanah, 2017)

$$
\text { Tingginya prevalensi penderita }
$$

Hiperkolesterolemia di Indonesia memunculkan berbagai upaya pengobatan, upaya pencegahan yang dapat dilakukan selain perawatan medis, perawatan non-farmakologi bisa juga dilakukan untuk mencegah dan menurunkan kadar kolesterol yang tinggi. selain itu pengobatan tradisional ini juga ekonomis dan mudah diperoleh (Hembing, 2009). Pengobatan tradisional terbukti secara alamiah aman dan bermanfaat dan dapat dikombinsikan dengan pengobatan konvensional sebagai pelengkapan (komplementer) pelayanan kesehatan konvensional atau terapi pengganti (alternatif) bila terapi konvensional tidak bisa diberikan (Kemenkes RI, 2012)

Apel sering dianjurkan untuk dikonsumsi para penderita kolesterol tinggi. Apel memang makanan bebas kolesterol sempurna yang dapat membantu untuk mempertahankan kadar kolesterol tetap rendah. Seperempat bagian dari buah apel terdiri atas pectin dan serat yang larut dalam air sehingga mampu menurunkan kadar LDL kolesterol yang dapat menyumbat pembuluh darah (Anies, 2015)

Kandungan serat pada apel sangat tinggi. serat sendiri merupakan nutrisi yang membantu kestabilan gula darah. serat juga mampu menghasilkan rasa kenyang yang lebih lama pada orang yang memakannya, sehingga baik bagi yang sedang diet. Serat yang berada di dalam buah apel juga berguna untuk mengikat lemak dan kolesterol jahat dalam tubuh (Jauhari, 2016)

Studi terbaru yang diterbitkan dalam Journal of Clinical Lipidology juga menyebutkan bahwa mengkonsumsi satu buah alpukat atau setengah secara teratur per hari, menunjukkan penurunan kadar kolesterol secara signifikan. Buah alpukat dipilih karena termasuk buah yang istimewa, mengandung lemak 20-30 kali lebih banyak dibandingkan dengan buah-buahan lainnya.

Buah alpukat memiliki kandungan lemak total sebanyak 15,41 gram/100 gram buah (National Nutrient Database for Standart Reference Release, 2012 dalam California Avocado Commision, 2015). Alpukat kaya akan protein, riboflavin (vitamin B2), niasin (vitamin B3), potasium (kalium), vitamin C, 
serta mengandung asam lemak omega-3 yang berguna untuk menjaga kesehatan jantung, menurunkan kolesterol dan merupakanan makanan bagi otak. MUFA (Monounsaturated Fatty Acid) atau asam lemak tak jenuh tunggal dalam alpukat berperan menurunkan kolesterol LDL (kolesterol jahat). Alpukat juga mengandung niasin yang dapat menaikkan jumlah kolesterol HDL (kolesterol baik). Adanya penurunan LDL dan peningkatan HDL akan mengakibatkan darah menjadi lancar dan mencegah terjadinya aterosklerosis (Helen, 2014). Para peneliti dari Hass Avocado Board, California mengatakan selain menurunkan kolesterol jahat memakan alpukat juga dapat menurunkan berat badan dan resiko penyakit jantung (Maharani, 2016).

Provinsi Riau termasuk lima besar tertinggi jumlah pengidap penyakit - penyakit hiperkolesterolemia. Posisi Riau berada satu tingkat di bawah Sumatera Barat, yang mana kadar kolosterol yang tinggi di Provinsi Riau meningkat dari tahun 2002 sampai tahun 2013 sebesar 45,3\% menjadi 63,7\% (Ahmad,2014 dalam Dewi, 2017)

Berdasarkan data dari Dinas Kesehatan Kabupaten Kampar Bangkinang tahun 2018, didapatkan bahwa jumlah kasus Hiperkolestrolemia tertinggi berada di Kecamatan Bangkinang Kota sebanyak 124 orang.

Berdasarkan latar belakang yang di atas maka peneliti tertarik untuk melakukan penelitian tentang "Studi Perbandingan Jus Apel dan Jus Alpukat Terhadap Penurunan Kadar Kolestrol pada Orang yang Mengalami Hiperkolestrolemia di Wilayah Kerja Puskesmas Bangkinang Kota"

\section{METODE PENELITIAN \\ Desain Penelitian}

Pada penelitian ini menggunakan jenis penilitian kuantitatif. Desain penilitian yang digunakan yaitu Quasi Experiment, dan rancangan yang digunakan two group pre-testposttest yaitu dengan mengobservasi sebanyak 2 kali sebelum dan sesudah diberikan perlakuan. Kelompok diobservasi sebelum dilakukan intervensi, kemudian diobservasi kembali setelah intervensi di lain waktu yang telah dilakukan (Setiadi, 2007).

\section{Lokasi dan Waktu Penelitian}

Lokasi penelitian dilakukan di Wilayah Kerja Puskemas Bangkinang Kota, pada tanggal 02 - 06 Agustus 2019.

\section{Populasi}

Populasi dalam penelitian adalah subjek yang memenuhi kriteria yang telah ditetapkan (Nursalam,2008). Populasi dalam penilitian ini adalah seluruh pasien yang menderita hiperkolesterolemia di Wilayah Kerja Puskesmas Bangkinang Kota pada katagori umur 45-54 tahun yang berjumlah 106 orang.

\section{Sampel}

"Sampel adalah objek yang di teliti dan dianggap mewakili seluruh populasi" (Notoatmodjo, 2012). Teknik pengambilan sampel yang dipakai yaitu non probabilitas dengan metode purposive sampling atau judgement sampling, dimana memilih sampel ini dengan cara memakai proses seleksi bersyarat (Kasjono dan Yasril, 2009). Jumlah sampel yang akan diteliti dalam penelitian ini berjumlah 20 orang, yang mana 10 responden diberikan Jus Apel dan 10 responden lagi diberikan Jus Alpukat, masing-masing selama 5 hari, dengan pemberian 1x sehari pada pagi hari.

\section{Alat Pengumpulan Data}

Alat pengumpulan data yang dipakai pada penelitian ini adalah :

1. Untuk variable Dependen yaitu kadar kolesterol, alat yang digunakan adalah set untuk cek kolesterol dengan menggunakan Easy Touch GCU dengan uji strip. Hasil dari pemeriksaan kadar kolesterol sebelum dan sesudah pemberian jus apel atau jus alpukat di dokumentasikan dalam lembaran ceklis yang sudah disiapkan sesuai dengan kebutuhan penelitian.

2. Untuk variable Independen yaitu : 
a) Jus apel alat yang dipakai adalah : 250 gram buah apel dan air $80 \mathrm{ml}$, blender, gelas pengukur untuk satu orang. Untuk 10 orang.

b) Jus alpukat alat yang dipakai adalah : 250 gram buah alpukat dan air $80 \mathrm{ml}$, blender, gelas pengukur untuk satu orang. Untuk 10 orang..

\section{Analisa Data}

Analisa data yang digunakan adalah analisa univariat dan analisa bivariat. Analisa univariat bertujuan untuk menjelaskan atau mendeskripsikan karakteristik setiap veriabel penilitian. Bentuk analisa univirat bergantung dari jenis datanya. Untuk data numeric digunakan nilai mean, median dan standar deviasi. Pada umumnya dalam analisis ini hanya menghasilkan distribusi frekuensi dan presentase dari setiap variabel. Analisa bivariat digunakan terhadap dua variable yang diduga berhubungan atau berkolaborasi (Notomatmodjo, 2010). Dalam penilitian ini analisa bivariate digunakan untuk menganalisa perbedaan pengaruh jus apel dan jus alpukat terhadap penurunan kadar kolesterol. Sehingga dalam analisis ini dapat digunakan uji statistic uji T-test atau Paired T-test yaitu uji dua mean dependen. Uji dua mean antara dua kelompok data yang dependen (Sunyoto, 2012).

\section{HASIL DAN PEMBAHASAN}

\section{Analisis Univariat}

Analisa univariat dilakukan untuk melihat kadar kolesterol sebelum mengkomsumsi jus apel dan jus alpukat. Berdasarkan Distribusi Frekuensi Kadar Kolesterol Sebelum Pemberian Jus Apel didapatkan hasil bahwa rata-rata kadar kolesterol sebelum pemberian jus apel adalah $256 \mathrm{mg} / \mathrm{dl}$. Selanjutnya dari Distribusi Frekuensi Kadar Kolesterol Sebelum Pemberian Jus Alpukat didapatkan hasil bahwa rata-rata kadar kolesterol sebelum pemberian jus alpukat adalah 249,2 mg/dl. Sedangkan Distribusi Frekuensi Kadar Kolesterol Sesudah Pemberian Jus Apel didapatkan hasil bahwa ratarata kadar kolesterol sesudah pemberian jus apel adalah 177,6 mg/dl. Selanjutnya berdasarkan distribusi Frekuensi Kadar Kolesterol Sesudah Pemberian Jus Alpukat didapatkan hasil bahwa rata-rata kadar kolesterol sesudah pemberian jus alpukat adalah 190,9 mg/dl.

\section{Analisa Bivariat}

Analisa ini menggunakan uji paired t test untuk melihat perbandingan kedua intervensi dalam menurunkan kadar kolesterol seperti yang terlihat pada tabel 4.5 berikut ini:

a. Pemberian Jus Apel

Efektifitas Pemberian Jus Apel dalam menurunkan Kadar Kolesterol pada orang yang mengalami Hiperkolesterol di Wilayah Kerja Puskesmas Bangkinang Kota tahun 2019 didapatkan hasil bahwa rata-rata kadar kolesterol sebelum diberikan jus apel yaitu $256 \mathrm{mg} / \mathrm{dl}$ dengan standar deviasi 28,686. Namun setelah diberikan jus apel selama 5 hari di dapat rata-rata kadar kolesterol sebesar 177,6 mg/dl dengan standar deviasi 28,733. Jadi selisih rata-rata kadar kolesterol sebelum dan sesudah minum jus apel sebanyak 78,4 mg/dl. Hasil uji statistic di dapatkan nilai $P$ value $0,000(\mathrm{p} \leq 0,05)$ yang artinya ada pengaruh pemberian jus apel terhadap kadar kolesterol pada penderita Hiperkolesterol Di Wilayah Kerja Puskesmas Bangkinang Kota.

b. Pemberian Jus Alpukat

Efektifitas Pemberian Jus Alpukat dalam menurunkan Kadar Kolesterol pada orang yang mengalami Hiperkolesterol di Wilayah Kerja Puskesmas Bangkinang Kota tahun 2019 didapatkan hasil bahwa rata-rata kadar kolesterol sebelum diberikan jus alpukat yaitu $249,2 \mathrm{mg} / \mathrm{dl}$ dengan standar deviasi 30,312. Namun setelah diberikan jus alpukat selama 5 hari di dapat rata-rata kadar kolesterol sebesar 190,9 mg/dl dengan standar deviasi 22,679. Jadi selisih rata-rata kadar kolesterol sebelum dan sesudah minum jus alpukat sebanyak 58,3 $\mathrm{mg} / \mathrm{dl}$. Hasil uji statistic di dapatkan nilai $P$ value $0,000 \quad(\mathrm{p} \leq 0,05)$ yang artinya ada pengaruh pemberian jus 
alpukat terhadap kadar kolesterol pada penderita Hiperkolesterol Di Wilayah Kerja Puskesmas Bangkinang Kota.

c. Perbandingan Pemberian Jus Apel dan Jus Alpukat

Perbandingan Efektifitas Pemberian Jus Apel dan Jus Alpukat dalam menurunkan Kadar Kolesterol pada orang yang mengalami Hiperkolesterol di Wilayah Kerja Puskesmas Bangkinang Kota tahun 2019 didapatkan hasil bahwa perbandingan rata-rata perbedaan kadar kolesterol pada kedua kelompok dapat dilihat dari selisih kadar kolesterol setelah diberikan intervensi antara pemberian jus apel dengan jus alpukat $(78,4$ : 58,3). Secara statistik terdapat pengaruh yang signifikan antara jus apel dan jus alpukat ( $\mathrm{p}$ value 0,000 dan 0,000) terhadap penurunan kadar kolesterol. Jika dibandingkan, pemberian jus apel lebih efektif menurunkan kadar kolesterol sebanyak 20,1 mg/dl kali dibandingkan dengan pemberian jus alpukat dalam menurunkan kadar kolesterol pada orang yang mengalami Hiperkolesterol di Wilayah Kerja Puskesmas Bangkinang Kota Tahun 2019

\section{PEMBAHASAN}

1. Kadar Kolesterol Sebelum dan Sesudah Mengkomsumsi Jus Apel

Hasil analisis data kadar kolesterol sebelum diberikan jus apel didapat rata-rata kadar kolesterol $256 \mathrm{mg} / \mathrm{dl}$ dan setelah diberikan jus apel 177,6. Dari hasil analisa tersebut menunjukkan bahwa adanya pengaruh pemberian jus apel terhadap penurunan kadar kolesterol pada penderita hiperkolesterolemia di wilayah kerja puskesmas bangkinang kota dengan $p$ value $0,000 \quad(\leq 0,05)$. Hal ini sejalan dengan penilitian Zukhri dkk dimana hasil penelitiannya terdapat pengaruh jus apel terhadap penurunan kadar kolesterol, dengan rata-rata penurunan kolesterol yaitu $19,7 \mathrm{mg} / \mathrm{dl}$.
2. Kadar Kolesterol Sebelum dan Sesudah Mengkomsumsi Jus Alpukat

Hasil analisis data kadar kolesterol sebelum diberikan jus apel didapat rata-rata kadar kolesterol 249,2 mg/dl dan setelah diberikan jus apel 190,9. Dari hasil analisa tersebut menunjukkan bahwa adanya pengaruh pemberian jus alpukat terhadap penurunan kadar kolesterol pada penderita hiperkolesterolemia di wilayah kerja puskesmas bangkinang kota dengan $p$ value $0,000(\leq 0,05)$. Hal ini sejalan dengan penilitian purwaningtyas dan kustiningsih dimana hasil penelitiannya terdapat pengaruh jus alpukat terhadap penurunan kadar kolesterol, dengan rata-rata penurunan yaitu $8,2 \mathrm{mg} / \mathrm{dl}$.

3. Perbandingan pemberian jus apel dengan jus alpukat terhadap kadar kolesterol

Hasil penilitian menunjukkan bahwa pemberian jus apel dan jus alpukat samasama berpengaruh menurunkan kadar kolesterol pada orang yang mengalami hiperkolesterolemia, dan berdasarkan hasil uji statistic baik jus apel dan jus alpukat sama-sama efektif dalam menurunkan kadar kolesterol ( $p$ value $0,000 \leq 0,05$ ) berdasarkan data nilai rata-rata penurunan kadar kolesterol pada kedua kelompok menunjukkan kelompok pemberian jus apel mempunyai rata-rata penurunan yang lebih besar dibanding kelompok pemberian jus alpukat, rata-rata penurunan pada kelompok pemberian jus apel sebesar 78,4 mg/dl sedangkan pada kelompok jus alpukat sebesar $58,3 \mathrm{mg} / \mathrm{dl}$.

Menurut asumsi peneliti jus apel dan jus alpukat memiliki kandungan yang dapat menurunakan kadar kolesterol, pactin dan niasin, namun pada Apel manalagi, dari 250 gr apel manalagi yang digunakan terdapat 5,25 gram serat pectin, pektin ini berperan dalam menurunkan kadar kolesterol dalam darah, dan pektin dapat menghambat reabsorsi asam empedu sehingga kadar kolesterol di ekskresikan 
lebih banyak melalui fases.. sedangkan pada 250 gram alpukat yang digunakan terdapat $4.37 \mathrm{mg}$ niasin, niacin ini berperan dalam menaikkan jumlah kolesterol baik HDL artinya tingginya kandungan pektin dapat mengikat banyak menurunkan kadar kolesterol.

Hal ini sejalan dengan penilitian Menisa di mana hasil penilitiannya yaitu jus apel lebih efektif dalam menurunkan kadar kolesterol di banding dengan jus wortel dengan rata-rata penurnunan yaitu 25,4 . Pektin dalam apel berperan sebagai anti inflamasi, efektifitas terhadap jenis kanker dan anti kolesterol. Pektin dapat meningkatkan kadar kolesterol baik HDL (High Density Lipoprotein) secara signifikan, dimana saat HDL (High Density Lipoprotein) meningkat maka HDL (High Density Lipoprotein) dapat menyingkirkan kolesterol jahat LDL (Low Density Lipoprotein). Apel Hijau juga memiliki karotin sebagai vitamin A dan antioksidan tinggi, dalam buah apel juga mengandung Vit $\mathrm{C}$ berfungsi membantu reaksi hidroksil dalam pembentukan garam empedu lalu terjadi ekresi kolesterol meningkat. Kalium di dalam jus apel berfungsi mengatur pengiriman zat-zat gizi ke sel-sel tubuh dan mengendalikan keseimbangan cairan pada jaringan dan sel tubuh dari fungsi diatas dapat menurunkan kadar kolesterol (lutfyanika (2014)

\section{SIMPULAN}

Setelah dilakukan peneliti tentang perbandingan efektifitas pemberian Jus Apel dan Jus Alpukat dalam menurunkan kadar kolesterol pada orang yang mengalami Hiperkolesterolemia di Wilayah Kerja Puskesmas Bangkinang Kota tahun 2019 terhadap 20 responden, maka dapat disimpulkan sebagai berikut:

1. Efektifitas pemberian Jus Apel dalam penurunan kadar kolesterol pada orang yang mengalami Hiperkolesterolemia di
Wilayah Kerja Puskesmas Bangkinang Kota Tahun 2019 ( $\mathrm{p}$ value $=0,000 \leq 0,05$ )

2. Efektifitas pemberian Jus Alpukat dalam penurunan kadar kolesterol pada orang yang mengalami Hiperkolesterolemia di Wilayah Kerja Puskesmas Bangkinang Kota Tahun 2019 ( $\mathrm{p}$ value $=0,000 \leq 0,05)$

3. Perbandingan efektifitas pemberian jus apel dan jus alpukat dalam menurunkan kadar kolesterol pada orang yang mengalami Hiperkolesterolemia di Wilayah Kerja Puskesmas Bangkinang Kota Tahun 2019

\section{SARAN}

Dari penelitian yang telah dilakukan, penulis memberikan saran-saran sebagai berikut :

1. Responden

Disarankan bagi responden untuk lebih memanfaatkan jus apel dalam menurunkan kadar kolesterol dengan tepat dan cepat.

\section{Puskesmas}

Disarankan kepada pihak Puskesmas untuk mensosialisaikan terapi komplementer dalam rangka menurunkan angka mortalitas hiperkolesterol.

3. Untuk Peneliti

Diharapkan untuk peneliti yang ingin mengembangkan penelitian ini dapat di analisis lagi secara multivariate, dan hasil penelitian ini dapat membantu untuk penelitian selanjutnya.

\section{DAFTAR PUSTAKA}

Alisna, (2017). "Pengaruh pemberian rebusan air daun sirsak terhadap kadar kolesterol pada pasien hiperkolesterolemia". Skripsi. Universitas Pahlawan Tuanku Tambusai Riau
Alodokter (2016) Kolesterol Tinggi. www.alodokter.com/kolesterol tinggi/2014. 
Amir.S (2012). Ajaibnya terapi herbal tumpas kolesterol. Jakarta: Dunia Sehat.

Anonim.(2015) . Badan Penelitin dan Pengembangan Pertanian. (http://www.pustaka-deptan.go.id. Di peroleh pada tanggal 25 mei 2019.

Botham. (2012). Harper's Illustrated Biochemistry: Cholesterol Synthesis, Transpor \& Excretion. Amerika Serikat: McGraw Hill.

Bull dan Morrell.(2007). Kolesterol. Jakarta : Erlangga.

Dewi, Ratna, (2017). "Pengaruh Pemberian Susu Kedelai Terhadap Kolesterol Darah Pada Penderita Hiperkolesterolemia”. Skripsi. Universitas Pahlawan Tuanku Tambusai Riau

Dickson. "Kandungan Gizi Buah Alpukat dan Manfaat Buah Alpukat Bagi Kesehatan". Artikel. Diperoleh pada tanggal 08 Juli 2019 dari $\mathrm{http} / / /$ ilmupengetahuanumum.com/kan dungan-gizi-buah-alpukat-danmanfaat-buah-alpukat-bagi-kesehatan/

Freeman, M, Junge, C. (2005). Kolesterol Rendah Jantung Sehat. Penerbit Buana Ilmu Populer.

Halifa. (2017). Pengaruh mengkomsumsi Buah Apel terhadap Tubuh Manusia. Universitas Muhammadiah Malang. Skripsi. Di Peroleh pada tanggal 25 Mei 2019 dari http://eprints.umm.ac.id/38202/3/BAB $\% 20 I I . p d f$.

Heryputra MJ.(2014). Hubungan antara kebiasaan minum teh dengan kadar kolesterol total pada pengunjung puskesmas kelurahan kedoya selatan. Skripsi. Fakultas Kedokteran Universitas Kristen Krida Wacana.

Hidayat, A.A. (2011). Metode Penelitian Keperawatan dan Teknik Analisa Data. Jakarta, Selemba Medika
Irianto, K. (2015). Memahami Berbagai Macam Penyakit. Bandung : Penerbit Alfabeta, cv.

Izzati, dkk (2018). "Pengaruh Jus Apel Hijau Terhadap Penurunan Kolesterol pada Penderita Hipertensi”. Jurnal. Stikes Yasri Sumbar Bukittinggi. http:// .......Di peroleh pada tanggal 15 April 2019.

Jauhary, H. (2016). Sehat Tanpa Obat dengan Apel. Yogyakarta : Andi Offset

Jevuska

http//www.jevuska.com/2013/06/03/ko lesterol-pengertian dan jenis-jenis kolesterol.

Kementrian Kesehatan RI (2013). Riset Kesehatan Dasar (Riskesdas). Jakarta: Kemenkes RI; 2013

Lestariunique (2013). Hiperkolesterolemia. http://lestariunique.wordspress.com/20 1/3/07/09/hiperkolesterolemia.

Maulidi (2016). Pengertian Kolesterol. www.kanal.id $>$ beranda $>$ kesehatan.

Nurpuspitasari, Amalia (2013). "Khasiat Pektin dalam buah Apel" Artikel. Diperoleh pada tanggal 08 Juli 2019. Dari

http://amalianurpuspitasari.blogspot.co $\mathrm{m} / 2013 / 04 /$ khasiat-pektin-dalam-buahapel.html?m=1

Mumpuni, Wulandari (2011). Sumber : National Institutes of Health, Detection, Evolution, dan Treatment fo High Blood Cholesterol in Adults III.

Notoatmodjo, Soekidjo (2010). Metodelogi Penelitian Kesehatan. Jakarta : Rineka Cipta

Nurman, dkk (2017). "Pengaruh Pektin Buah Apel (Mulus Sylvestris Mill) Terhadap Kadar LDL Kolesterol”. Jurnal. Universitas Andalas. http:// ....Di peroleh pada tanggal 15 April 2019.

Nurrahmani, U. (2012). Stop Kolesterol Tinggi. Yogyakarta : Falima (Group Relasi Intimedia). 
UPT. Puskesmas Bangkinang Kota. (2018).

Jumlah Penderita Kadar Kolesterol

Tinggi: Kabupaten Kampar

Sumber : Data Dinas Kesehatan Kabupaten

Kampar, 2018

Wurdianing I.(2014). Efek ekstrak daun sirsak

(Annona muricata Linn) terhadap profil lipid tikus putih jantan (Rattus Norvegicus). Jurnal Gizi Indonesia (ISSN : 1858-4942). Balai Pelatihan Kesehatan, Kota Semarang Fakultas Kesehatan Masyarakat, Universitas Diponegoro, Indonesia.

Yuwinanda, (2017). "Perbandingan Konsumsi Jus Buah Mengkudu dengan Kapsul Ekstrak Mengkudu terhadap Tekanan Darah pada Penderita Hipertensi". Skripsi. Universitas Pahlawan Tuanku Tambusai Riau 